\title{
PELATIHAN IMPLEMENTASI ATMABOT SEBAGAI ROBOT ASISTEN DOKTER DAN PERAWAT DI RUMAH SAKIT ATMA JAYA
}

\section{Linda Wijayanti' ${ }^{1}$, Nova Eka Budiyanta ${ }^{2}$, V. Budi Kartadinata ${ }^{3}$, Widodo Widjaja Basuki ${ }^{4}$, dan Harlianto Tanudjaja ${ }^{5}$}

\author{
${ }^{1}$ Program Studi Teknik Elektro, Universitas Katolik Indonesia Atma Jaya Jakarta \\ Email: linda.wijayanti@atmajaya.ac.id \\ ${ }^{2}$ Program Studi Teknik Elektro, Universitas Katolik Indonesia Atma Jaya Jakarta \\ Email: nova.eka@atmajaya.ac.id \\ ${ }^{3}$ Program Studi Profesi Insinyur, Universitas Katolik Indonesia Atma Jaya Jakarta \\ Email: budi.kartadinata@atmajaya.ac.id \\ ${ }^{4}$ Program Studi Teknik Mesin, Universitas Katolik Indonesia Atma Jaya Jakarta \\ Email: widodo.basuki@atmajaya.ac.id \\ ${ }^{5}$ Program Studi Sistem Informasi, Universitas Katolik Indonesia Atma Jaya Jakarta \\ Email: harlianto.tj@atmajaya.ac.id
}

\begin{abstract}
Since the Covid-19 outbreaks in Indonesia, the number of positive cases has continued to grow. Hospitals are at a very high risk of being the site of the spread of Covid-19, resulting in problems with the many cases of doctors and nurses who contracted Covid-19 from their patients. Therefore, a robot is needed to reduce direct contact between doctors and nurses with Covid-19 patients. The Faculty of Engineering, Unika Atma Jaya, in collaboration with Alumni of the Faculty of Engineering, has succeeded in making a robot to help doctors and nurses serve Covid-19 patients with mild and moderate symptoms, who are still able to carry out activities independently. The robot, named AtmaBot, was made to be handed over to the Atma Jaya Hospital. AtmaBot is equipped with a camera for video calls between doctors and nurses and patients, helping to reduce direct contact between doctors, nurses with patients. AtmaBot can also deliver food, drinks, medicine, and other equipment, controlled by remote control or laptop. The handover of AtmaBot has carried out at Campus 3 BSD, followed by training on its use. The training is carried out by using the lecture method and practicing how to operate the AtmaBot for doctors and nurses' representatives. The training participants are expected to become trainers for doctors and other nurses at Atma Jaya Hospital. With this training, AtmaBot is expected to help doctors and nurses in isolation rooms, reducing the risk of doctors and nurses being infected with Covid-19.
\end{abstract}

Keywords: robot, AtmaBot, Covid-19, doctor, nurse

\begin{abstract}
ABSTRAK
Sejak kasus Covid-19 merebak di Indonesia, jumlah kasus positif masih terus bertambah setiap harinya. Hal ini membuat keprihatinan tersendiri, khususnya bagi dokter dan perawat di rumah sakit, yang setiap hari berinteraksi langsung dengan pasien. Rumah sakit berisiko sangat tinggi menjadi tempat penyebaran Covid-19, sehingga timbul permasalahan banyaknya kasus dokter dan perawat yang tertular Covid-19 dari pasiennya. Oleh karena itu diperlukan sebuah robot agar kontak langsung antara dokter dan perawat dengan pasien Covid-19 dapat dikurangi. Fakultas Teknik Unika Atma Jaya bekerja sama dengan Alumni Fakultas Teknik telah berhasil membuat sebuah robot untuk membantu dokter dan perawat dalam melayani pasien Covid-19 dengan gejala ringan dan sedang, yang masih dapat beraktivitas secara mandiri. Robot yang diberi nama AtmaBot ini dibuat untuk dihibahkan kepada Rumah Sakit Atma Jaya. AtmaBot dilengkapi kamera untuk video call antara dokter dan perawat dengan pasien, sehingga membantu mengurangi kontak langsung dokter dan perawat dengan pasien. AtmaBot juga dapat mengantarkan makanan, minuman, obat-obatan, dan perlengkapan lainnya ke kamar isolasi, dengan dikendalikan oleh remote control maupun laptop. Serah terima AtmaBot dilakukan di Kampus 3 BSD, dilanjutkan dengan pelatihan untuk penggunaannya. Pelatihan dilakukan dengan metode ceramah dan mempraktikkan langsung cara mengoperasikan AtmaBot kepada perwakilan dokter dan perawat. Peserta pelatihan diharapkan menjadi trainer bagi dokter dan perawat lainnya di RS Atma Jaya. Dengan pelatihan ini diharapkan AtmaBot dapat dimanfaatkan secara maksimal dalam membantu dokter dan perawat di kamar isolasi, sehingga mengurangi risiko dokter dan perawat terinfeksi Covid-19 dari pasiennya.
\end{abstract}

Kata Kunci: robot, AtmaBot, Covid-19, dokter, perawat 


\section{PENDAHULUAN}

Dalam masa pandemi Covid-19, meskipun peningkatan kasus positif semakin tinggi, rumah sakit tetap harus melayani masyarakat yang membutuhkan pelayanan kesehatan (WHO, 2020). Rumah sakit Atma Jaya juga mendukung program pemerintah dalam mengatasi pandemi dan membantu pasien yang terinfeksi Covid-19. Sebagian besar pasien yang terinfeksi memiliki gejala ringan dan sedang, yang membutuhkan perawatan di kamar isolasi. Hanya sebagian kecil pasien yang mengalami gejala berat yang membutuhkan penanganan khusus di ruang ICU.

Pasien dengan gejala ringan dan sedang yang dirawat di kamar isolasi umumnya masih dapat beraktivitas secara mandiri. Setiap hari pasien perlu dilayani dan bertemu dengan dokter, perawat, petugas gizi yang menyediakan dan mengantarkan makanan/minuman, serta petugas yang mengantarkan kebutuhan lain pasien. Kunjungan dokter kepada pasien dilakukan minimal sekali sehari. Perawat yang melakukan pemeriksaan darah, suhu, tekanan darah, atau pemeriksaan medis lainnya harus mendatangi kamar pasien beberapa kali dalam sehari. Petugas gizi yang mengantarkan makanan dan minuman minimal 3 kali sehari mendatangi kamar pasien.

Covid-19 merupakan penyakit infeksi dari virus yang tingkat penularannya sangat tinggi, artinya sangat mudah menular dari orang yang terinfeksi pada orang lain. Oleh karena dokter dan perawat sering berinteraksi langsung dengan pasien, maka risiko tertularnya menjadi sangat tinggi (WHO, 2020). Untuk mengurangi risiko dokter dan perawat tertular, maka kontak langsung dengan pasien harus dikurangi (Mahdi, 2020). Solusi yang diusulkan adalah dengan bantuan robot sebagai sarana komunikasi daring (video call) dengan pasien dan untuk mengantar makanan, minuman, obat, maupun kebutuhan lain kepada pasien (Geng Yang, et al, 2020).

Lingkup pengembangan robot di era modern ini sangatlah luas, mulai dari pengembangan platform robotika untuk mendukung pembelajaran (Budiyanta, 2020 dan Grzegorz, 2013), pengembangan ilmu robotika itu sendiri (Mohd, 2018) sampai pengembangan untuk mendukung Healthcare System. Seperti dikembangkan dalam proyek AtmaBot ini yang dirancang untuk memenuhi kebutuhan di Rumah Sakit Atma Jaya, yaitu membantu dokter dan perawat dalam melayani pasien Covid-19, yang dirawat di kamar isolasi, agar mengurangi kontak langsung dengan pasien (WHO, 2020). Dengan bantuan robot dalam melayani sebagian besar kebutuhan pasien, maka kontak langsung dengan pasien dapat dikurangi, agar risiko dokter dan perawat tertular dapat diperkecil (Nugraheny, 2020). Pengabdian ini bertujuan untuk memberikan pelatihan kepada tenaga dokter dan perawat dalam menjalankan fungsi AtmaBot untuk melayani pasien di ruang isolasi. Pelatihan juga diberikan kepada tenaga teknologi informasi dan maintenance agar instalasi dan pemeliharaan dapat dilakukan setelah AtmaBot dimanfaatkan di Rumah Sakit Atma Jaya.

Rancangan AtmaBot terdiri dari perangkat keras berupa laptop, tablet PC, access point wifi, remote control, robot dengan komponen elektronik, motor penggerak, dan sensor-sensornya, yang dilengkapi beberapa program perangkat lunak untuk menjalankan beberapa fungsi, yaitu:

1. Komunikasi dokter dengan pasien dapat digantikan dengan video call melalui laptop dan tablet PC yang terdapat pada robot.

2. Membawa makanan, minuman, obat, dan kebutuhan lain ke kamar pasien.

3. Untuk pasien yang dapat melakukan pengukuran suhu, tekanan darah, detak jantung, dan pengukuran lainnya secara mandiri dapat menginformasikan melalui tablet PC pada robot dan dapat dilihat oleh perawat di ruang kontrol untuk dicatat pada rekam medis pasien.

\section{METODE PELAKSANAAN PKM}

Pelatihan dilaksanakan di Unika Atma Jaya, Kampus 3 BSD, pada tanggal 5 Agustus 2020 dengan mengundang perwakilan dokter, perawat, tenaga IT, dan maintenance RS Atma Jaya. Pelaksanaan pelatihan hanya diberikan pada perwakilan staf RS Atma Jaya, karena kondisi PSBB yang 
membatasi pertemuan orang dalam jumlah besar. Metode pelaksanaan pelatihan dilakukan dengan ceramah dan praktik penggunaan AtmaBot dengan langkah-langkah operasi yang telah disediakan pada Manual Book AtmaBot (Gambar 1), yang diberikan dalam bentuk cetakan/hard file dan soft file.

Pelatihan dengan tatap muka diperlukan agar praktik penggunaan AtmaBot dapat dipahami dan dipraktikkan secara langsung oleh pengguna. Pelatihan ini dimaksudkan sebagai training of trainer, sehingga peserta pelatihan dapat menjadi trainer bagi dokter, perawat, tenaga IT, dan maintenance yang belum mengikuti pelatihan ini. Dengan demikian akan semakin banyak dokter dan perawat yang mampu menjalankan AtmaBot.

Pelaksanaan pelatihan dilakukan dengan memberikan ceramah penjelasan cara kerja, fungsi tombol-tombol pada AtmaBot, dan aplikasi yang digunakan untuk menjalankan AtmaBot. Kemudian dokter dan perawat melakukan praktik secara langsung cara mengaktifkan dan menjalankan AtmaBot menggunakan remote control maupun laptop, mengaktifkan komunikasi video call antara laptop dengan tablet PC, dan semua hal penting tentang AtmaBot. Setelah dokter dan perawat paham cara penggunaan AtmaBot, kemudian dijelaskan cara membersihkan dan mensterilkan AtmaBot, mengisi batere AtmaBot, laptop, dan tablet PC, serta hal lain yang perlu dilakukan agar AtmaBot dapat berfungsi dengan baik di RS Atma Jaya.

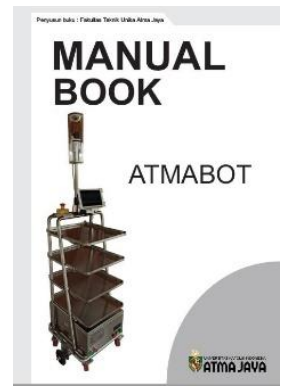

Gambar 1 Manual Book AtmaBot

\section{HASIL DAN PEMBAHASAN}

AtmaBot merupakan hasil rancangan sekelompok dosen, karyawan, dan mahasiswa Fakultas Teknik Unika Atma Jaya. Perancangan dimulai saat Covid-19 mulai muncul di Indonesia yang bersamaan dengan masa seluruh kegiatan kampus dilakukan secara daring dari rumah (Karina, 2020). Analisis kebutuhan pengguna (user requirement) diwakili oleh dokter RS Atma Jaya yang dilakukan dengan komunikasi secara daring dengan tim perancang. Setelah dilakukan perancangan, perakitan, pengujian perangkat keras dan perangkat lunak, terakhir dilakukan pengujian sistem secara keseluruhan. Selanjutnya setelah pengujian dinyatakan berhasil, AtmaBot dihibahkan kepada RS Atma Jaya dalam rangka membantu dokter dan perawat dalam melayani pasien Covid-19 (Karina, 2020). Serah terima AtmaBot dari Rektor Unika Atma Jaya kepada Direktur Utama RS Atma Jaya (Gambar 2) dilaksanakan pada tanggal 5 Agustus 2020 di Kampus 3 Unika Atma Jaya, yang berlokasi di BSD, Tangerang Selatan (Unika Atma Jaya, 2020). Setelah serah terima, acara dilanjutkan dengan pelatihan mengoperasikan AtmaBot kepada beberapa dokter dan perawat, serta tenaga IT, dan maintenance RS Atma Jaya (Gambar 3).

Pelatihan yang diberikan kepada staf RS ATma Jaya dilakukan dengan menjalankan langsung AtmaBot pada selasar ruang kuliah Kampus 3 BSD sebagai simulasi selasar ruang isolasi di RS Atma Jaya. Robot dijalankan dari ujung selasar menuju ruang kuliah sebagai simulasi dari ruang perawat ke ruang isolasi di rumah sakit. Pelatihan menggunakan buku panduan Manual Atmabot yang dibuat oleh tim pengabdian (Fakultas Teknik Unika Atma Jaya, 2020). Tahapan proses pelatihan dan praktik penggunaan AtmaBot yang dilakukan dijelaskan pada bagian berikut. 


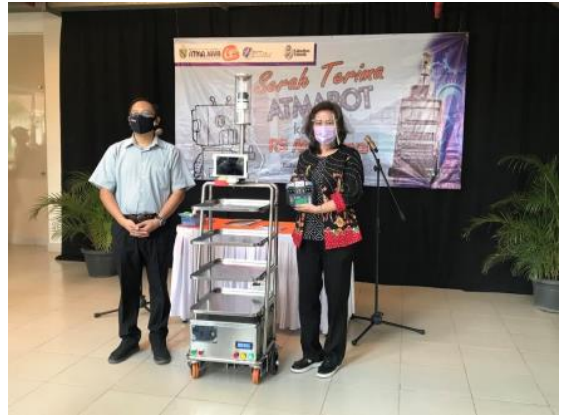

Gambar 2. Serah terima AtmaBot

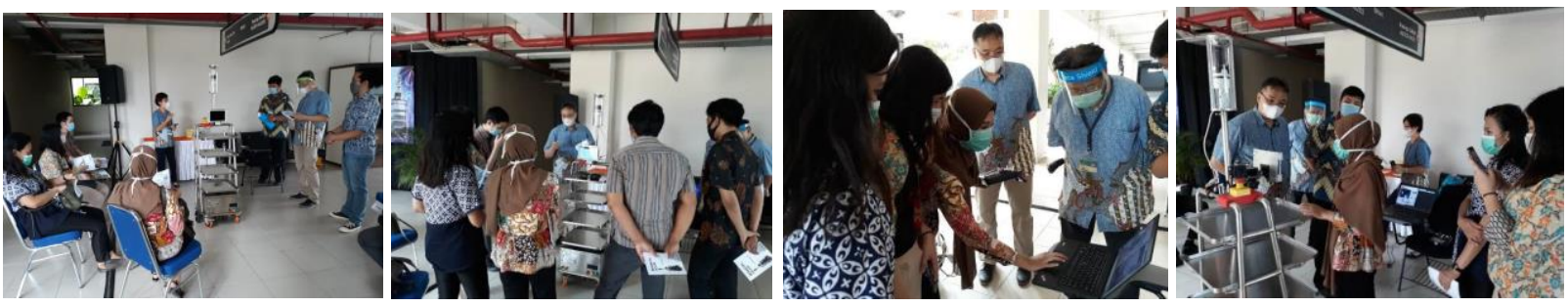

Gambar 3. Kegiatan pelatihan

\section{Menyalakan dan mematikan laptop}

Laptop dinyalakan dengan menekan tombol power (Gambar 4), ditunggu hingga semua proses pada laptop selesai, kemudian server yang ada di dalam virtual box menyala secara otomatis. Server ini digunakan sebagai server video call pada robot. Setelah tampilan laptop seperti Gambar 5, maka proses sudah selesai dan cukup minimize aplikasinya, tidak perlu login. Apabila belum berhasil, maka perlu klik aplikasi Ubuntu yang berada di desktop laptop.

Proses mematikan laptop dengan menutup aplikasi kendali Atmabot, yaitu menekan button disconnect, kemudian klik close (x). Selanjutnya mematikan server Atmabot dengan klik Machine, lalu klik ACPI Shutdown. Setelah server telah tidak aktif, kemudian shutdown laptop.

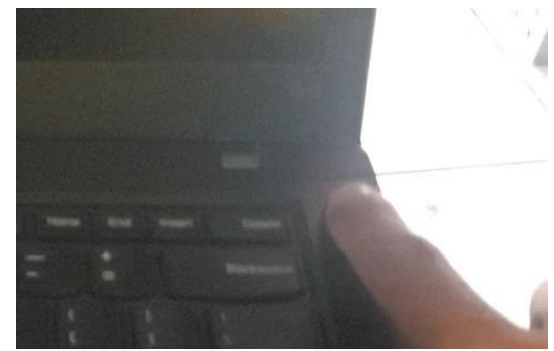

Gambar 4. Tombol Power pada Laptop

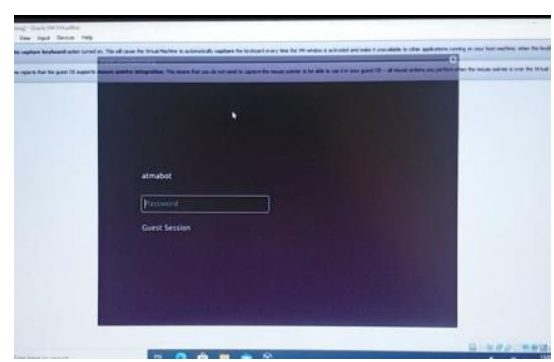

Gambar 5. Tampilan Aplikasi 


\section{Menyalakan dan mematikan tablet}

Cara menyalakan tablet dengan menekan tombol daya Gambar 6, kemudian tunggu hingga proses booting selesai.

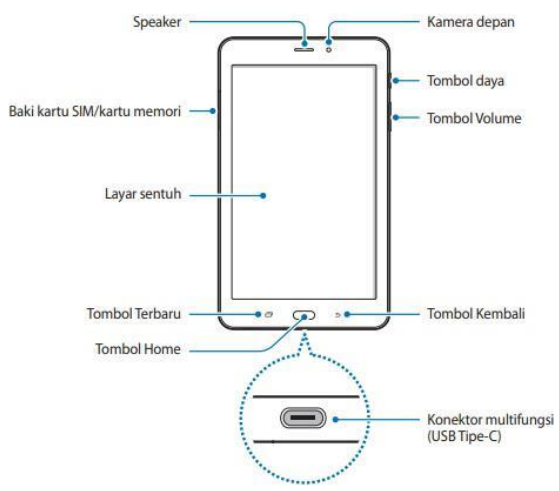

Gambar 6. Bentuk tablet dan fungsinya

\section{Mengaktifkan Atmabot}

Untuk mengaktifkan AtmaBot dilakukan dengan memindahkan saklar power yang berada di bagian belakang panel AtmaBot ke bagian "ON" (kanan). Saklar ini berfungsi untuk menghubungkan panel dengan power yang berasal dari baterai, sehingga semua komponen elektronik dalam AtmaBot menjadi aktif. Jika saklar power dipindah ke sebelah kiri yaitu "CHARGE", maka berubah ke kondisi charging (pengisian daya) sehingga tidak dapat digunakan untuk beroperasi. Pada saat saklar power ON, maka indikator lampu kuning pada bagian depan panel menyala. Hal ini menandakan bahwa robot sudah memiliki daya untuk beroperasi.

Setelah itu tekan saklar merah yang berada dibawah saklar power ke posisi ON, yang berfungsi untuk mengaktifkan LCD di bagian depan panel menyala. Pada LCD ditampilkan beberapa informasi AtmaBot, seperti nilai digital dari jarak sensor ultrasonik dengan halangan pada bagian kanan, kiri, dan belakang AtmaBot. Selain itu juga terdapat informasi mengenai daya baterai, tegangan pada robot, arus robot, dan kondisi baterai robot tersebut (need charging atau ready).

Sebelum menyalakan motor robot, pastikan tombol Emergency Stop sudah di release. Apabila tombol emergency stop belum release, maka daya tidak dapat mengalir ke motor, sehingga motor tidak dapat berfungsi. Untuk release dilakukan dengan memutar tombol Emergency Stop.

Tahap berikutnya mengaktifkan motor dengan menekan push button hijau di bagian depan panel, ditandai dengan lampu hijau menyala. Robot siap dioperasikan ketika access point dengan SSID robot sudah muncul, access point dan SSID robot inilah yang digunakan untuk transfer data dari Atmabot ke laptop maupun dari laptop ke Atmabot.

Default kendali gerak Atmabot adalah menggunakan remote control. Kamera dan seluruh sensor dapat dipantau melalui software yang diinstal pada laptop. Kendali gerak dapat diubah melalui keyboard laptop, dengan klik Mode Laptop pada layar laptop. Untuk mengembalikan ke default remote control, klik Mode Remote pada layar laptop dan harus mereset robot dengan cara mematikan Atmabot sesaat dan menyalakannya kembali.

\section{Instalasi jaringan dan software AtmaBot}

Kondisi server otomatis dalam keadaan aktif ketika laptop dinyalakan. Jika tampilan server mengganggu, dapat diminimize, tetapi tidak boleh di close. Ubiquiti atau repeater sebaiknya diletakkan di tengah antara kamar isolasi terjauh dan ruang kontrol. Repeater siap digunakan 
apabila lampu indikator pada repeater menyala berwarna biru dan pada laptop akan terdeteksi SSID Rack001.

Untuk menyambungkan laptop dengan access point Atmabot dapat dilakukan dengan 2 cara, yaitu menggunakan SSID 'robots' untuk komunikasi jarak dekat tanpa repeater, atau menggunakan SSID 'Rack001' untuk jarak komunikasi yang lebih jauh dengan repeater.

Untuk membuka software Atmabot dengan klik dua kali icon software Atmabot yang terdapat pada desktop laptop. Tunggu sampai jendela software Atmabot terbuka seperti Gambar 7. Jika muncul indikator 'Connected' seperti pada Gambar 8, klik "OK”. Untuk mempermudah klik 'OK' pada message box, tampilkan message box di depan aplikasi.

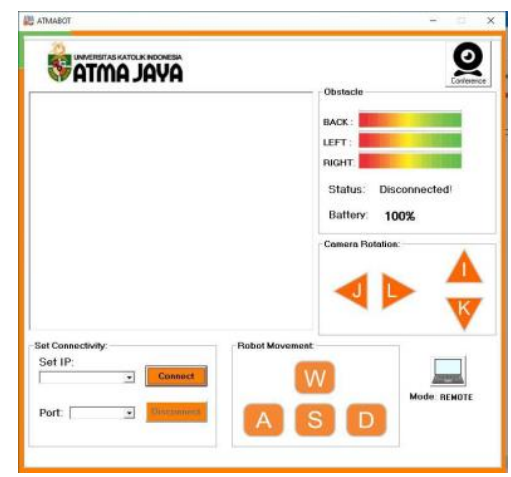

Gambar 7. Aplikasi AtmaBot

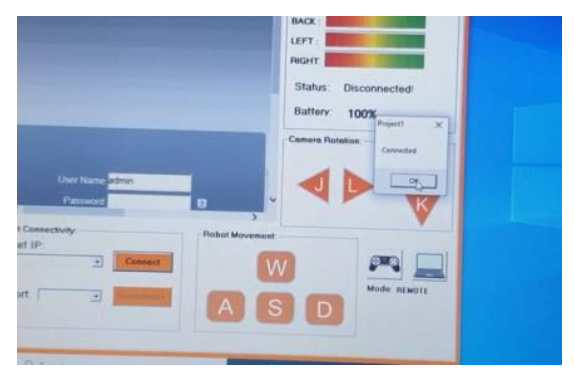

Gambar 8. Koneksi ke AtmaBot

\section{Mengendalikan Atmabot menggunakan remote control}

Kondisi Atmabot sudah diaktifkan dan siap untuk dijalankan. Remote control dinyalakan dengan cara menggeser switch on/off yang terletak di kanan bawah ke posisi On, yaitu dengan menggeser ke atas sampai LCD menyala. Untuk memulai kendali gerak AtmaBot, turunkan analog sebelah kiri sampai tampilan LCD berubah dan segera kembalikan analog kiri ke posisi tengah. Jika tidak ingin menggerakkan stepper tablet, pastikan analog kiri selalu di tengah.

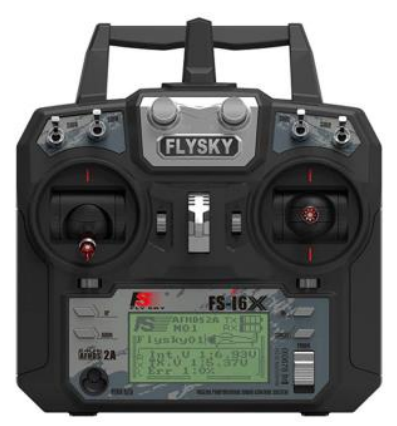

Gambar 9. Remote Control AtmaBot 
Fungsi dari setiap analog pada remote control AtmaBot (Gambar 9) adalah sebagai berikut:

- Analog Kiri digeser ke atas untuk memutar motor posisi tablet mengarah ke atas.

- Analog Kiri digeser ke bawah untuk memutar motor posisi tablet mengarah ke bawah.

- Analog Kiri digeser ke kiri untuk memutar motor posisi tablet mengarah ke kiri.

- Analog Kiri digeser ke kanan untuk memutar motor posisi tablet mengarah ke kanan.

- Analog Kanan digeser ke atas untuk menggerakkan AtmaBot maju.

- Analog Kanan digeser ke bawah untuk menggerakkan AtmaBot mundur.

- Analog Kanan digeser ke kanan untuk menggerakkan AtmaBot ke kanan.

- Analog Kanan digeser ke kiri untuk menggerakkan AtmaBot ke kiri.

\section{Mengendalikan AtmaBot menggunakan laptop dari ruang kontrol dokter/perawat}

Pastikan AtmaBot sudah terhubung dengan laptop. Untuk mulai menampilkan video dari omnidirectional camera (omni camera/omni cam), dimulai dengan klik login. Jika button login tidak terlihat, bisa scroll ke bawah pada slider jendela omni cam. Jika muncul jendela seperti Gambar 10, silakan klik "OK”.

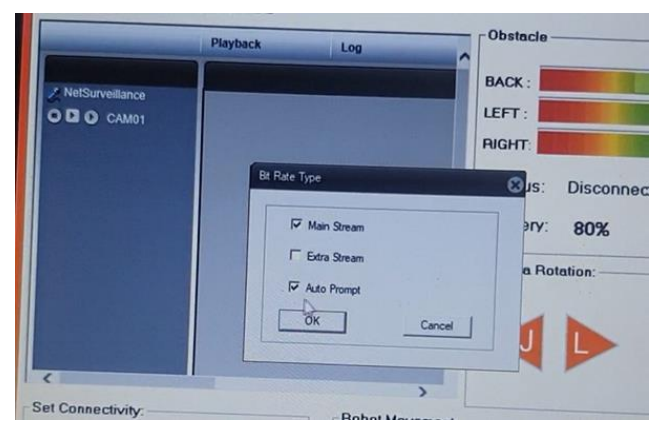

Gambar 10. Jendela Pengaturan Bit Rate pada Omni cam

Untuk menampilkan video omni cam berada pada posisi tengah, dilakukan secara manual dengan cara menggeser slider horisontal dan vertikal. Jika posisi tampilan omni cam sudah berada di tengah berarti siap digunakan. Dengan melihat Gambar 11 bagian kiri bawah, Set Connectivity pada kolom Set IP dengan cara drop down diisi 192.168.1.20. Lakukan hal yang sama pada kolom Port diisi 1500. Klik button 'Connect' untuk menghubungkan aplikasi dengan kendali gerak Atmabot. Jika muncul pesan 'Connected' klik button 'OK'. Indikator bahwa sistem telah terkoneksi ditunjukkan dengan perubahan Status dari 'Disconnected' menjadi 'Connected'. Klik button bergambar laptop pada sudut kanan bawah aplikasi, sehingga Mode 'Remote' berubah menjadi 'Laptop'. Atmabot dapat digerakkan dengan menekan huruf ASWD dan untuk tablet dengan menekan huruf JKIL pada keyboard laptop, dengan fungsi tombol dinyatakan pada Tabel 1 .

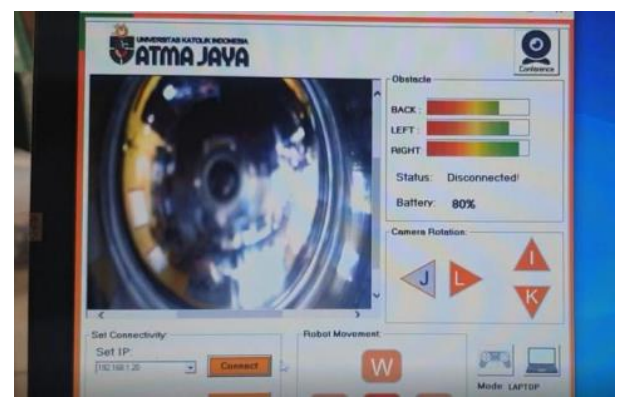

Gambar 11. Tampilan Omni Cam Yang Siap Digunakan 
Tabel 1. Fungsi Tombol Control AtmaBot Pada Aplikasi

\begin{tabular}{cccc}
\hline & Control Robot & \multicolumn{2}{c}{ Control Tablet } \\
\hline W & Maju & I & Tablet Naik \\
\hline S & Mundur & K & Tablet Turun \\
\hline A & Kiri & J & Tablet ke Kiri \\
\hline D & Kanan & L & Tablet ke Kanan \\
\hline
\end{tabular}

\section{Mengaktifkan video call untuk komunikasi dokter/perawat dengan pasien}

Klik simbol 'Conference' yang ada pada sebelah kanan atas aplikasi. Halaman Browser Firefox akan terbuka secara otomatis, menampilkan halaman conference. Jika muncul tampilan seperti Gambar 12, klik "Allow" untuk memberi ijin akses kamera dan microphone. Setelah mendapat akses kamera dan microphone, maka laptop siap menerima client Conference dari tablet yang terpasang pada Atmabot.

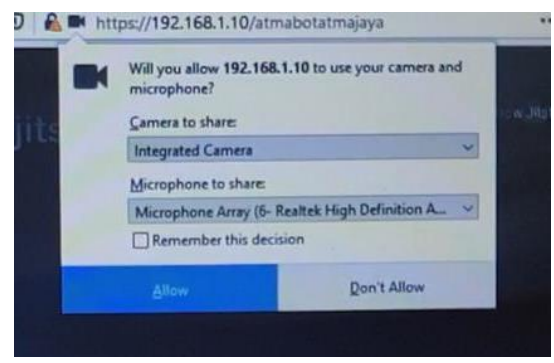

Gambar 12. Cara Mengakses Kamera dan Microphone pada Laptop

Tablet yang terpasang pada Atmabot dinyalakan dan dimasukkan password yang sesuai. Sambungkan tablet dengan access point pada Atmabot. Pastikan tablet terkoneksi dengan Atmabot melalui access point "robots". Kemudian klik browser Chrome yang ada pada halaman depan tablet, maka secara otomatis halaman akan diarahkan ke server Conference, dengan tampilan seperti Gambar 13 (a).

Langkah selanjutnya adalah mengaktifkan 'desktop site' pada browser tablet, dengan cara membuka pengaturan browser lalu cari Desktop site, klik pada pilihan desktop site tersebut (Gambar 13 (b)). Fasilitas Conference sudah siap digunakan untuk komunikasi antara dokter/perawat yang menggunakan laptop di ruang kontrol dan pasien yang menggunakan tablet yang terpasang pada AtmaBot di kamar isolasi.

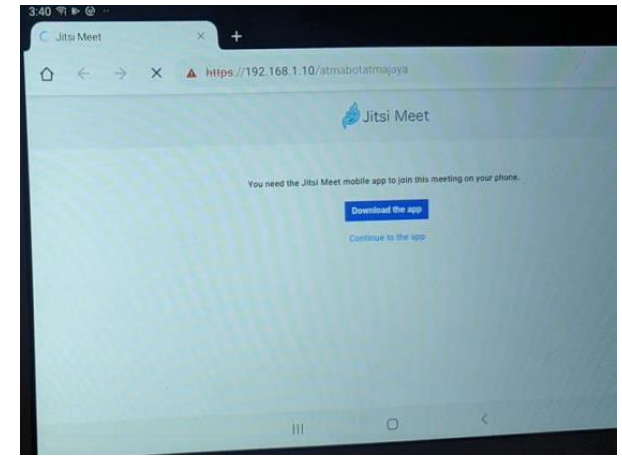

(a)

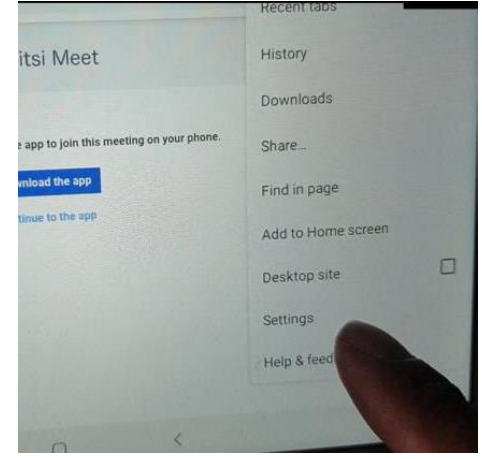

(b)

Gambar 13. Tampilan (a) Browser Setelah Tablet Terhubung Access Point (b) Tombol Desktop Site pada Tablet 


\section{Mengoperasikan emergency stop}

Emergency stop digunakan untuk memutus supply daya menuju motor penggerak Atmabot, sehingga ketika emergency stop diaktifkan, gerakan Atmabot akan berhenti (Gambar 14). Emergency stop digunakan sebagai pengaman apabila robot berada di luar kendali. Untuk mengaktifkan emergency stop dengan menekan tombol emergency stop yang berwarna merah. Untuk menonaktifkan emergency stop dilakukan dengan memutar tombol emergency stop.

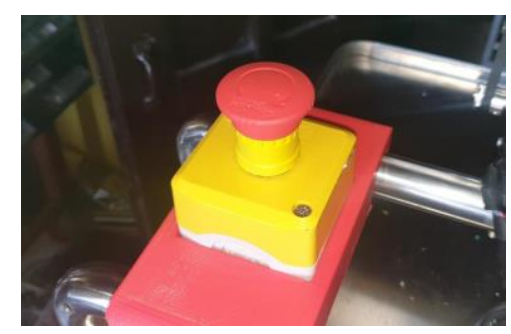

Gambar 14. Emergency Stop

\section{Mengisi/charge baterai Atmabot}

Pengisian baterai atmabot dilakukan dengan menggeser Switch utama ke arah kiri (Mode Charging). Pastikan indikator lampu berwarna merah di panel depan Atmabot menyala. Pasangkan kabel AC Charger pada slot input AC dengan sumber arus AC.

\section{Tips memelihara baterai}

- Tablet dianjurkan untuk di charge ketika indikator baterai di batas bawah $20 \%$.

- Laptop dianjurkan di charge ketika indikator baterai di batas bawah $20 \%$.

- Baterai Atmabot harus segera di charge ketika indikator baterai pada LCD Atmabot menunjukkan 'LOW' atau indikator pada aplikasi menunjukkan 'Need Charging'.

\section{Membersihkan dan sterilisasi AtmaBot}

- Untuk membersihkan dan sterilisasi rak, dilakukan dengan melepas dan mencuci rak menggunakan sabun dan air mengalir, kemudian dikeringkan sebelum dipasang kembali.

- Untuk membersihkan rangka Atmabot dapat dilakukan menggunakan lap basah kemudian dikeringkan. Pastikan tidak ada cairan yang masuk ke dalam box panel Atmabot karena cairan dapat mengakibatkan kerusakan komponen elektronik di dalam box panel.

- Untuk membersihkan laptop dan tablet dilakukan dengan lap kering.

\section{Hal-hal yang perlu diperhatikan}

- Untuk makanan cair dalam mangkok bubur/sup dan minuman dalam gelas, wajib ditutup dengan plastik wrap agar tidak tumpah.

- Saat box panel Atmabot dipasang maupun dilepas, tidak diperbolehkan diletakkan dengan posisi terbalik, pastikan pintu panel Atmabot selalu berada pada posisi atas.

- Pemeliharaan dan pemeriksaan secara berkala sangat diperlukan untuk menjaga Atmabot tetap bisa bekerja dengan maksimal, terutama perawatan dan pelumasan pada bagian roda dan Gearbox Atmabot.

\section{KESIMPULAN}

Pelatihan implementasi AtmaBot sebagai robot asisten dokter dan perawat telah dilaksanakan bagi perwakilan dokter, perawat, tenaga IT, dan maintenance. Dengan penggunaan AtmaBot di RS Atma Jaya akan mengatasi permasalahan kontak langsung dengan pasien, sehingga mengurangi terjadinya risiko penularan Covid-19 dari pasien kepada tenaga medis dan tenaga kesehatan. 
Ucapan Terima Kasih (Acknowledgement)

Pelaksana kegiatan penelitian dan pelatihan menyampaikan terima kasih kepada Rektor, Dekan Fakultas Teknik, Ketua Lembaga Penelitian dan Pengabdian Masyarakat, dan Alumni Fakultas Teknik Unika Atma Jaya atas dukungan dan kerja samanya dalam proses pembuatan AtmaBot. Terima kasih juga kami sampaikan kepada Direktur Rumah Sakit Atma Jaya sebagai mitra yang memanfaatkan AtmaBot, dan seluruh staf yang telah mengikuti pelatihan ini.

\section{REFERENSI}

Budiyanta, N. E., Sereati, C. O., Lukas, (2020). P-D controller computer vision and robotics integration based for student's programming comprehension improvement. TELKOMNIKA (Telecommunication Computing Electronics and Control), 18(2), 899-906.

Fakultas Teknik Unika Atma Jaya (2020). Manual Book ATMABOT.

Geng Yang, Honghao Lv, Zhiyu Zhang, Liu Yang, Jia Deng, Siqi You, Juan Du, Huayong Yang (2020). Keep Healthcare Workers Safe: Application of Teleoperated Robot in Isolation Ward for COVID-19 Prevention and Control. Chinese Journal of Mechanical Engineering, $33(47), 1-4$.

Grzegorz C., Nicola B., Tom D., Integrating Mobile Robotics and Vision with Undergraduate Computer Science. IEEE Transaction on Education. 2013; 56(1): 48-53.

Karina Chrisyantia (2020). Untuk Kurangi Kontak Fisik Tenaga Medis dan Pasien Covid 19, Unika Atma Jaya Luncurkan AtmaBot. https://www.hidupkatolik.com/2020/08/05/48007/untuk-kurangi-kontak-fisik-tenagamedis-dan-pasien-covid-19-unika-atma-jaya-luncurkan-atmabot/. Diakses 19 September 2020.

Mahdi Tavakoli, Jay Carriere, Ali Torabi (2020). Robotics, Smart Wearable Technologies, and Autonomous Intelligent Systems for Healthcare During the COVID-19 Pandemic: An Analysis of the State of the Art and Future Vision. Advanced Intelligent Systems, 2(7), 1-7.

Mohd RMS., Khalil AMA., Synchronous Mobile Robots Formation Control, TELKOMNIKA (Telecommunication Computing Electronics and Control). 2018; 16(3), 1183-1192.

Nugraheny, Dian Erika (2020). 117 Dokter Meninggal Terpapar Covid-19, IDI: Masyarakat Masih Abai. https://nasional.kompas.com/read/2020/09/18/10455351/117-doktermeninggal-terpapar-covid-19-idi-masyarakat-masih-abai. Diakses 19 September 2020.

Unika Atma Jaya (2020). Atma Jaya University Launches AtmaBot to Aid Medical Workers Amid COVID-19. https://qswownews.com/atma-jaya-university-launches-atmabot-to-aidmedical-workers-amid-covid-19/. Diakses 19 September 2020.

Unika Atma Jaya (2020). Unika Atma Jaya Luncurkan AtmaBot Untuk Melayani Pasien Covid19. https://m.atmajaya.ac.id/web/Konten.aspx?gid=highlight\&cid=launching-atmabot. Diakses 19 September 2020.

WHO Coronavirus Disease (COVID-19) Dashboard (2020). Keep health workers safe to keep patients safe: WHO. https://www.who.int/news-room/detail/17-09-2020-keep-healthworkers-safe-to-keep-patients-safe-who. Diakses 19 September 2020.

WHO Coronavirus Disease (COVID-19) Dashboard (2020). https://covid19.who.int/table. Diakses 19 September 2020. 